\title{
Impact of Azoxystrobin, Dimethomorph, Fluazinam, Fosetyl-Al, and Metalaxyl on Growth, Sporulation, and Zoospore Cyst Germination of Three Phytophthora spp.
}

\author{
M. E. Matheron, Extension Plant Pathologist, and M. Porchas, Research Specialist, University of Arizona, Yuma \\ Agricultural Center, Yuma 85364
}

\begin{abstract}
Matheron, M. E., and Porchas, M. 2000. Impact of azoxystrobin, dimethomorph, fluazinam, fosetyl-Al, and metalaxyl on growth, sporulation, and zoospore cyst germination of three Phytophthora spp. Plant Dis. 84:454-458.

In vitro activity of azoxystrobin, dimethomorph, and fluazinam on growth, sporulation, and zoospore cyst germination of Phytophthora capsici, P. citrophthora, and P. parasitica was compared to that of fosetyl-Al and metalaxyl. The $50 \%$ effective concentration $\left(\mathrm{EC}_{50}\right)$ values for inhibition of mycelial growth of the three pathogens usually were lowest for dimethomorph and metalaxyl, ranging from $<0.1$ to $0.38 \mu \mathrm{g} / \mathrm{ml}$. However, the $90 \%$ effective concentration $\left(\mathrm{EC}_{90}\right)$ levels for dimethomorph always were lower than the other four tested compounds, with values ranging from 0.32 to $1.6 \mu \mathrm{g} / \mathrm{ml}$. Mycelial growth of $P$. capsici, $P$. citrophthora, and $P$. parasitica was least affected by azoxystrobin and fluazinam, with estimated $\mathrm{EC}_{90}$ values $>3,000 \mu \mathrm{g} / \mathrm{ml}$. Reduction of sporangium formation by P. capsici, P. citrophthora, and P. parasitica in the presence of dimethomorph at $1 \mu \mathrm{g} / \mathrm{ml}$ was significantly greater than that recorded for the same concentration of azoxystrobin, fluazinam, and fosetyl-Al. For the three species of Phytophthora, zoospore motility was most sensitive to fluazinam $\left(\mathrm{EC}_{50}\right.$ and $\mathrm{EC}_{90}$ values of $\left.<0.001 \mu \mathrm{g} / \mathrm{ml}\right)$ and least sensitive to fosetyl-Al, with $\mathrm{EC}_{50}$ and $\mathrm{EC}_{90}$ values ranging from 299 to 334 and 518 to 680 $\mu \mathrm{g} / \mathrm{ml}$, respectively. Germination of encysted zoospores of $P$. capsici, $P$. citrophthora, and $P$. parasitica was most sensitive to dimethomorph $\left(\mathrm{EC}_{50}\right.$ and $\mathrm{EC}_{90}$ values ranging from 3.3 to 7.2 and 5.6 to $21 \mu \mathrm{g} / \mathrm{ml}$, respectively), intermediate in sensitivity to fluazinam $\left(\mathrm{EC}_{50}\right.$ and $\mathrm{EC}_{90}$ from 18 to 108 and 67 to $>1,000 \mu \mathrm{g} / \mathrm{ml}$, respectively) and metalaxyl $\left(\mathrm{EC}_{50}\right.$ and $\mathrm{EC}_{90}$ from 32 to 280 and 49 to $529 \mu \mathrm{g} / \mathrm{ml}$, respectively), and lowest in sensitivity to azoxystrobin and fosetyl-Al $\left(\mathrm{EC}_{50}\right.$ and $\mathrm{EC}_{90}$ from 256 to $\left.>1,000 \mu \mathrm{g} / \mathrm{ml}\right)$. The activity of azoxystrobin, dimethomorph, and fluazinam on one or more stages of the life cycle of P. capsici, P. citrophthora, and P. parasitica suggests that these compounds potentially could provide Phytophthora spp. disease control comparable to that of the established fungicides fosetyl-Al and metalaxyl.
\end{abstract}

Diseases caused by species of the genus Phytophthora continue to inflict significant losses on numerous important crops worldwide (11). Among these diseases are gummosis and root rot of citrus caused by $P$. citrophthora and $P$. parasitica and crown and root rot of pepper (Capsicum annuum) caused by $P$. capsici, diseases of importance in Arizona $(22,25)$ as well as other regions where these crops are grown. The impact of Phytophthora spp. on food and fiber production is revealed by the large number of publications from throughout the world that deal with every aspect of this genus of plant pathogenic organisms (29). Losses attributable to Phytophthora spp. diseases of some tree fruit and vegetable crops in the United States have been reduced through the use of the systemic fungicides fosetyl-Al (Aliette, RhonePoulenc Ag Co., Research Triangle Park,

Corresponding author: M. E. Matheron

E-mail: matheron@ag.arizona.edu

Accepted for publication 20 December 1999.

Publication no. D-2000-0204-01R

(C) 2000 The American Phytopathological Society
NC) or metalaxyl (Ridomil, Novartis Crop Protection, Greensboro, NC) $(25,28,30,31)$. Recently, some other chemistries have been reported to have activity on some species of Phytophthora, including azoxystrobin (Abound, Zeneca Ag Products, Wilmington, DE; 15), dimethomorph (Acrobat, American Cyanamid Co., Princeton, NJ; 7,21), and fluazinam (Zeneca Ag Products; 9,33).

The objective of the following study was to evaluate and compare the in vitro impact of azoxystrobin, dimethomorph, fosetyl$\mathrm{Al}$, fluazinam, and metalaxyl on growth, sporulation, and zoospore cyst germination of P. capsici, P. citrophthora, and P. parasitica. Preliminary accounts of this research were reported earlier $(23,24)$.

\section{MATERIALS AND METHODS}

Fungi and fungicides. One isolate each of $P$. capsici, $P$. citrophthora, and $P$. parasitica was used in these investigations. The isolate of $P$. capsici was recovered from a chile-pepper plant in a commercial field in southeastern Arizona, whereas isolates of $P$. citrophthora and P. parasitica originated from infected citrus trees in western and central commercial orchards of the state. The following formulations of tested fungicides were used in all experiments: azoxystrobin (Abound 80WG), dimethomorph (Acrobat 50WP), fluazinam (Fluazinam 50WP), fosetyl-Al (Aliette 80WDG), and metalaxyl (Ridomil 2E) .

Mycelial growth. Each species of Phytophthora was grown on V-8 juice agar (V8A; commercial V-8 juice, $200 \mathrm{ml}$; $\mathrm{CaCO}_{3}, 2 \mathrm{~g}$; agar, $17 \mathrm{~g}$; and distilled water, $800 \mathrm{ml}$ ) plates at $24^{\circ} \mathrm{C}$ for 5 days. Individual agar disks (6 $\mathrm{mm}$ in diameter) were removed from the edge of an actively growing culture of each pathogen and placed at the edge of a plastic Petri dish (9 $\mathrm{cm}$ in diameter) containing corn meal agar (CMA; $17 \mathrm{~g}$ of Difco corn meal agar in 1 liter of distilled water) amended with a test fungicide at concentrations of $0.1,1,10$, 100, 1,000, and 3,000 $\mu \mathrm{g}$ a.i./ml. Fungicides were added to CMA after autoclaving when the agar had cooled to approximately $55^{\circ} \mathrm{C}$. Control Petri dishes contained only CMA. Five replicate plates of each fungicide concentration as well as controls were prepared for each species of Phytophthora. After a 4-day incubation period at $24^{\circ} \mathrm{C}$ in darkness, the radial growth of mycelia was measured.

Sporangium formation. Sporangia were produced by growing the Phytophthora spp. on V8A plates as described earlier. Four agar disks (6 $\mathrm{mm}$ in diameter) were removed from the edge of an actively growing culture of each isolate and placed in a series of plastic Petri dishes $(60 \mathrm{~mm}$ in diameter) containing $7 \mathrm{ml}$ of $1.5 \%$ nonsterile soil extract amended with one of the test fungicides to give a final concentration of $1,10,100$, or $1,000 \mu \mathrm{g}$ a.i./ml. Nonsterile soil extract was prepared by mixing 15 $\mathrm{g}$ of a sandy loam orchard soil in 1 liter of distilled water with a magnetic stirrer for 8 $\mathrm{h}$ at $25 \pm 2^{\circ} \mathrm{C}$. After an additional 16-h incubation period without stirring, the coarse soil particles settled to the bottom of the container and the remaining suspension was decanted and used as the soil extract. Five replicate plates of each fungicide concentration, in addition to control plates containing nonsterile soil extract without fungicides, were prepared for each species of Phytophthora. Following a 4day incubation period at $24^{\circ} \mathrm{C}$ in darkness, the liquid was decanted from each Petri dish and the agar disks were stained and fixed with acid fuchsin in $85 \%$ lactic acid. The number of sporangia along the margins of each agar disk was counted.

Zoospore motility, encystment, and germination. Sporangia were produced as 
described above by placing four V8A disks (6 $\mathrm{mm}$ in diameter) from the edge of an actively growing culture of each species of Phytophthora into a series of plastic Petri dishes (60 $\mathrm{mm}$ in diameter) containing 7 $\mathrm{ml}$ of $1.5 \%$ nonsterile soil extract, then incubating these dishes in darkness at $24^{\circ} \mathrm{C}$ for 4 days. Sporangia were induced to release zoospores by chilling at $4{ }^{\circ} \mathrm{C}$ for 20 min. After rewarming at $25^{\circ} \mathrm{C}$ for $20 \mathrm{~min}$, agar disks and attached mycelia were removed from each Petri dish and the volume of the remaining zoospore suspension was determined. Aqueous mixtures of each fungicide at a concentration of $0.002,0.02$, $0.2,2,20,200$, and 2,000 $\mu \mathrm{g}$ a.i./ml were added to equal volumes of the zoospore suspensions, giving final concentrations of $0.001,0.01,0.1,1,10,100$, and $1,000 \mu \mathrm{g}$ a.i./ml. Control zoospore suspensions received an equal volume of water only. Zoospore suspensions were maintained at $25^{\circ} \mathrm{C}$ and observed microscopically at $75 \times$ to determine the maximum elapsed time for complete cessation of motility. Observations were made at 1-min intervals for the first $15 \mathrm{~min}$, then at 15 -min intervals for the next $45 \mathrm{~min}$, and finally at 1 -h intervals until no zoospore movement was detected.

The majority of zoospore cysts were adhering to the bottom of each plastic Petri dish. To determine the viability of these encysted zoospores, the aqueous treatment mixture was decanted and replaced with 5 $\mathrm{ml}$ of $5 \%$ clarified sterile V-8 juice broth ( $\mathrm{V}-8$ juice centrifuged for $10 \mathrm{~min}$ at 1,000 $\times g$, after which the supernatant is diluted with sterile water). Petri dishes containing encysted zoospores were incubated at $24^{\circ} \mathrm{C}$ and examined after 24 and $48 \mathrm{~h}$ for the appearance of mycelial growth arising from germinating cysts. The number of colonies appearing on each plate were recorded.

Analysis of data. Each experiment in this study was conducted twice. Data from repeated experiments were combined for analysis, because variances between experiments were homogeneous. All data were processed with the SigmaStat statistical software package (SPSS Science, Chicago). Error bars represent $95 \%$ confidence intervals (Fig. 1). Means with nonoverlapping $95 \%$ confidence intervals were considered significantly different (16). For each species of Phytophthora, the concentration of each fungicide causing $50 \%$ $\left(\mathrm{EC}_{50}\right)$ or $90 \%\left(\mathrm{EC}_{90}\right)$ reduction in mycelial growth, sporulation, duration of zoospore motility, and zoospore cyst germination compared to the absence of the fungicide was estimated from the fitted regression line of the logit-transformed percent inhibition plotted against the log-transformed fungicide concentration (4).

\section{RESULTS}

Mycelial growth. $\mathrm{EC}_{50}$ values for inhibition of mycelial growth of $P$. capsici, $P$. citrophthora, and $P$. parasitica usually were lowest for dimethomorph and metalaxyl, ranging from $<0.1$ to $0.38 \mu \mathrm{g} / \mathrm{ml}$ (Table 1). However, the $\mathrm{EC}_{90}$ levels for dimethomorph always were lower than the other four tested compounds, with values ranging from 0.32 to $1.6 \mu \mathrm{g} / \mathrm{ml}$. Mycelial growth of $P$. capsici, $P$. citrophthora, and $P$. parasitica was least affected by azoxystrobin and fluazinam, with estimated $\mathrm{EC}_{90}$ values $>3,000 \mu \mathrm{g} / \mathrm{ml}$ (Table 1). Reduction of mycelial growth of $P$. capsici, $P$. citrophthora, and $P$. parasitica by dimethomorph at a concentration of $1 \mu \mathrm{g} / \mathrm{ml}$ was significantly greater than that recorded for the same concentration of azoxystrobin, fluazinam, fosetyl-Al, and metalaxyl (Fig. 1). At a concentration of $1,000 \mu \mathrm{g} / \mathrm{ml}$, inhibition of mycelial growth for the three pathogens was significantly greater in the presence of dimethomorph, fosetyl-Al, and metalaxyl compared to azoxystrobin and fluazinam. In the absence of a fungicide, the average mycelial growth for $P$. capsici, $P$. citrophthora, and $P$. parasitica on CMA after 4 days at $24^{\circ} \mathrm{C}$ was 33,44 , and 24 $\mathrm{mm}$, respectively.

Sporangium formation. Estimated $\mathrm{EC}_{50}$ values for inhibition of sporangium formation by $P$. capsici, $P$. citrophthora, and $P$. parasitica ranged from $<1.0$ to 5.0 $\mu \mathrm{g} / \mathrm{ml}$ for azoxystrobin, dimethomorph, fluazinam, and metalaxyl. In comparison, $\mathrm{EC}_{50}$ values recorded for the three pathogens in the presence of fosetyl-Al ranged from 3.1 to $12.0 \mu \mathrm{g} / \mathrm{ml}$. The $\mathrm{EC}_{90}$ concentration for the three tested species of Phytophthora ranged from $<1.0 \mu \mathrm{g} / \mathrm{ml}$ for dimethomorph to a high of $208 \mu \mathrm{g} / \mathrm{ml}$ for fosetyl-Al (Table 1). Reduction of sporangium formation by $P$. capsici, $P$. citrophthora, and $P$. parasitica in the presence of dimethomorph at $1 \mu \mathrm{g} / \mathrm{ml}$ was significantly greater than that recorded for the same concentration of azoxystrobin, fluazinam, and fosetyl-Al (Fig 1). Formation of sporangia by $P$. capsici and $P$. citrophthora was totally suppressed by dimethomorph at $1.0 \mu \mathrm{g} / \mathrm{ml}$. In comparison, a 10 - to 1,000-fold higher concentration of azoxystrobin, fluazinam, fosetyl-Al, and metalaxyl was required to achieve the same result. Sporangium formation by $P$. parasitica was completely arrested by dimethomorph or metalaxyl at $10 \mu \mathrm{g} / \mathrm{ml}$; whereas, a 10- to 100-fold higher concentration of the other tested chemistries was required to achieve the same result. The average number of sporangia developing in soil extract in the absence of a fungicide after 4 days at $24^{\circ} \mathrm{C}$ from an agar disk containing mycelia of $P$. capsici, $P$. citrophthora, and $P$. parasitica was 470 , 500, and 498, respectively.

Zoospore motility, encystment, and germination. Among the five chemicals tested, the duration of motility for zoospores of P. capsici, P. citrophthora, and $P$. parasitica was most sensitive to fluazinam $\left(\mathrm{EC}_{50}\right.$ and $\mathrm{EC}_{90}$ values of $<0.001 \mu \mathrm{g} / \mathrm{ml}$;
Table 1). In contrast, zoospore motility of these pathogens among tested compounds was affected least by fosetyl-Al, with respective $\mathrm{EC}_{50}$ and $\mathrm{EC}_{90}$ values ranging from 299 to 334 and 518 to $680 \mu \mathrm{g} / \mathrm{ml}$. The percent reduction in the duration of motility for zoospores of $P$. capsici, $P$. citrophthora, and $P$. parasitica in the presence of fluazinam at concentrations ranging from 0.001 to $1 \mu \mathrm{g} / \mathrm{ml}$ was significantly higher than that observed for azoxystrobin, dimethomorph, fosetyl-Al, and metalaxyl at the same levels (Fig 1). On the other hand, at a concentration of $1,000 \mu \mathrm{g} / \mathrm{ml}$, all tested materials reduced zoospore motility by at least $98 \%$ compared to zoospores not exposed to a fungicide. Zoospores of $P$. capsici, $P$. citrophthora, and $P$. parasitica not treated with a fungicide retained their motility for at least 187, 142, and $203 \mathrm{~min}$, respectively.

Germination of encysted zoospores of $P$. capsici, $P$. citrophthora, and $P$. parasitica was most sensitive to dimethomorph among tested compounds, with $\mathrm{EC}_{50}$ and $\mathrm{EC}_{90}$ values ranging from 3.3 to 7.2 and 5.6 to $21 \mu \mathrm{g} / \mathrm{ml}$, respectively (Table 1 ). Among the five chemicals tested, the highest $\mathrm{EC}_{50}$ and $\mathrm{EC}_{90}$ values for the three pathogens generally were recorded for azoxystrobin and fosetyl-Al, ranging from 256 to $>1,000 \mu \mathrm{g} / \mathrm{ml}$. Intermediate sensitivity of encysted zoospores was noted for fluazinam $\left(\mathrm{EC}_{50}\right.$ and $\mathrm{EC}_{90}$ values ranging from 18 to 108 and 67 to $>1,000 \mu \mathrm{g} / \mathrm{ml}$, respectively) and metalaxyl $\left(\mathrm{EC}_{50}\right.$ and $\mathrm{EC}_{90}$ values ranging from 32 to 280 and 49 to $529 \mu \mathrm{g} / \mathrm{ml}$, respectively; Table 1$)$. Inhibition of zoospore cyst germination for $P$. capsici, $P$. citrophthora, and $P$. parasitica in the presence of dimethomorph at 10 $\mu \mathrm{g} / \mathrm{ml}$ was significantly higher than that recorded for azoxystrobin, fluazinam, fosetyl-Al, and metalaxyl at the same concentration (Fig 1). Inhibition of zoospore cyst germination for the three species of Phytophthora was achieved with at least $100 \mu \mathrm{g} / \mathrm{ml}$ of dimethomorph and 1,000 $\mu \mathrm{g} / \mathrm{ml}$ of metalaxyl, but not with 1,000 $\mu \mathrm{g} / \mathrm{ml}$ of azoxystrobin, fluazinam, or fosetyl-AL.

\section{DISCUSSION}

The ultimate value of any chemical compound as a control agent for a disease depends on the mode of action of the molecule at the physiological level on one or more components of the life cycle of the pathogen. Considering all the stages in the life cycle of soilborne Phytophthora spp., sporangium formation and zoospore release provide the greatest opportunity for a rapid buildup in the number of infective propagules and subsequent higher potential for host infection and disease development $(10,18,32)$. Therefore, any chemical that significantly suppresses formation of sporangia, duration of zoospore motility, or germination of encysted zoospores should reduce the ability of Phytophthora spp. to 

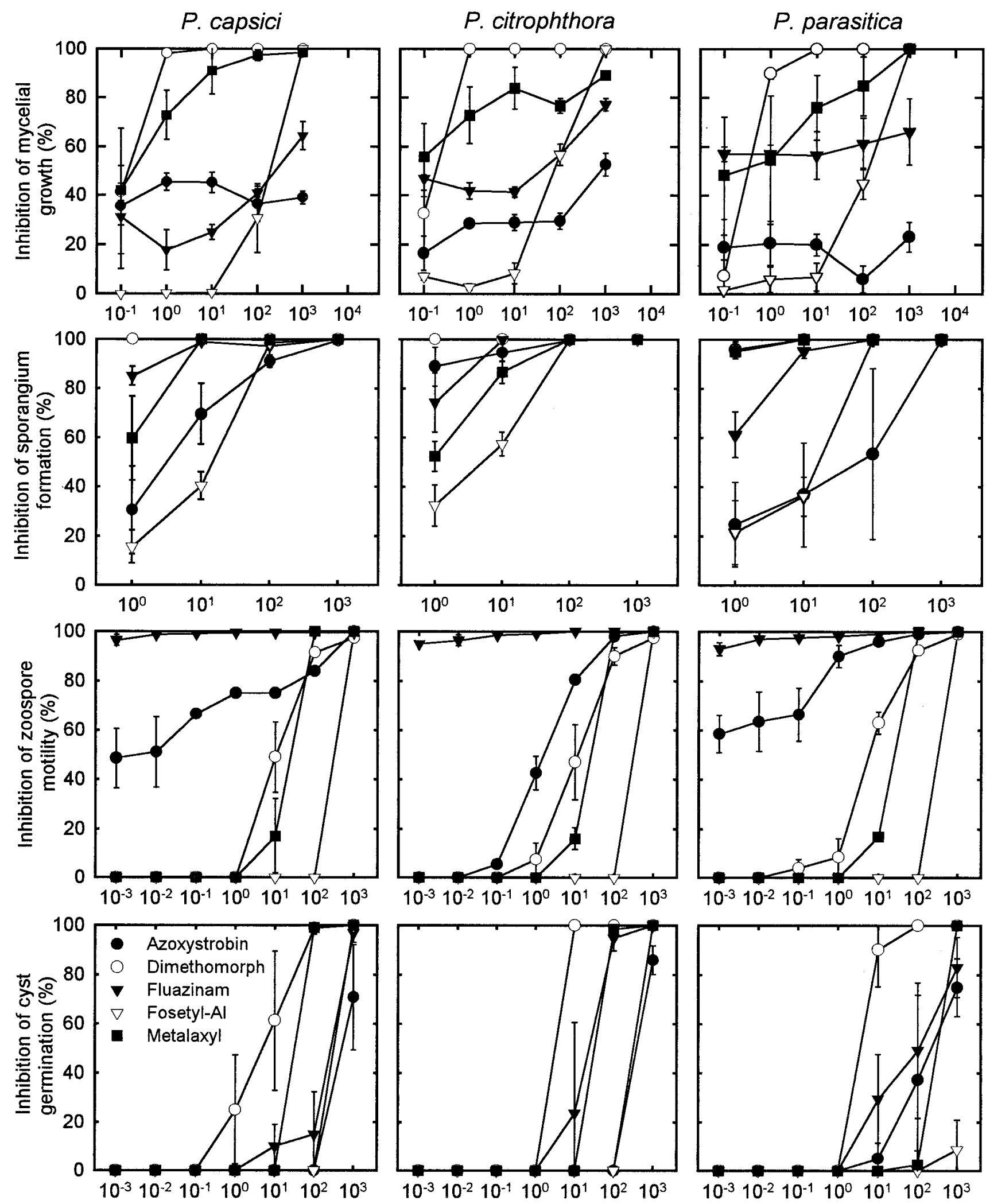

Fungicide concentration ( $\mu \mathrm{g}$ a.i./ml)

Fig. 1. Influence of dose of azoxystrobin, dimethomorph, fluazinam, fosetyl-Al, and metalaxyl on inhibition of mycelial growth, sporangium formation, zoospore motility, and germination of encysted zoospores of Phytophthora capsici, P. citrophthora, and P. parasitica. 
cause disease. At appropriate concentrations, azoxystrobin, dimethomorph, fluazinam, fosetyl-Al, and metalaxyl completely prevented sporangium formation and normally reduced the duration of zoospore motility and germination of encysted zoospores significantly compared to nontreated controls, thus severely restricting the potential of $P$. capsici, $P$. citrophthora, and $P$. parasitica to infect plant tissue and cause disease. Among the components of the life cycle of the Phytophthora spp. tested, all five fungicides had the greatest impact on inhibition of sporangium formation.

Once infection has occurred, suppression of mycelial growth within host tissue becomes an important disease management consideration. Among the tested chemicals, mycelial growth of the three tested Phytophthora spp. was most sensitive to dimethomorph at $1 \mu \mathrm{g} / \mathrm{ml}$. At higher concentrations, fosetyl-Al and metalaxyl effectively suppressed mycelial growth as well, whereas azoxystrobin and fluazinam were significantly less effective.

The effect of fosetyl-Al and metalaxyl on growth and sporulation of Phytophthora spp. has been studied extensively (11). For inhibition of mycelial growth of $P$. capsici by fosetyl-Al, Fenn and Coffey (14) found $\mathrm{EC}_{50}$ and $\mathrm{EC}_{90}$ values of 50 and $196 \mu \mathrm{g} / \mathrm{ml}$, respectively. For the same compound, Farih and Menge (12) calculated EC 50 values of 56 and $285 \mu \mathrm{g} / \mathrm{ml}$ for inhibition of mycelial growth of $P$. citrophthora and 929 and $1,146 \mu \mathrm{g} / \mathrm{ml}$ for $P$. parasitica, where the smaller value for each pathogen was determined after a 3-day period of growth on V-8 juice agar containing the fungicide and the larger value was ascertained after 7 days. Sporangium formation by $P$. citrophthora and $P$. parasitica was prevented by fosetyl-Al at 5 and $10 \mu \mathrm{g} / \mathrm{ml}$, respectively, whereas germination of zoospores of these two pathogens was reduced 53 and $99 \%$, respectively, by $1,000 \mu \mathrm{g} / \mathrm{ml}$ of the compound (12). In another published report (6), fosetyl-Al at a concentration of $2.9 \mu \mathrm{g} / \mathrm{ml} \mathrm{resulted} \mathrm{in} 56$ and $75 \%$ inhibition of sporangium formation by $P$. cinnamomi and $P$. citricola, respectively. Our findings on the relative sensitivity of mycelial growth, sporangium formation, and zoospore cyst germination to fosetyl-Al generally agree with these other published data.

Previously determined $\mathrm{EC}_{50}$ values for inhibition of mycelial growth of $P$. cinnamomi, $P$. citrophthora, and $P$. parasitica by metalaxyl ranged from 0.04 to $0.56 \mu \mathrm{g} / \mathrm{ml}$ $(2,13)$. Furthermore, Fariah et al. (13) reported that sporangium formation by $P$. citrophthora and $P$. parasitica was reduced 67 and $85 \%$, respectively, in the presence of metalaxyl at $0.1 \mu \mathrm{g} / \mathrm{ml}$, whereas zoospore germination was reduced 52 and $7 \%$, respectively, in the presence of metalaxyl at $100 \mu \mathrm{g} / \mathrm{ml}$. These concentrations of metalaxyl are in the same order of magnitude as our determinations of $\mathrm{EC}_{50}$ for mycelial growth as well as inhibition of sporangium formation and zoospore germination for $P$. citrophthora and $P$. parasitica.

Published accounts on the impact of azoxystrobin, dimethomorph, and fluazinam on growth and sporulation of Phy- tophthora spp. are less numerous than those concerning fosetyl-Al and metalaxyl. Godwin et al. (17) reported that azoxystrobin affects Phytophthora spp. primarily by inhibiting germination of sporangia and zoospores. In contrast, our data suggest that azoxystrobin is more active in suppression of sporangium formation (mean $\mathrm{EC}_{90}$ value of $29.2 \mu \mathrm{g} / \mathrm{ml}$ ) and zoospore motility (mean $\mathrm{EC}_{90}$ value of $14.5 \mu \mathrm{g} / \mathrm{ml}$ ) than inhibition of zoospore cyst germination $\left(\mathrm{EC}_{90}\right.$ value $\left.>1,000 \mu \mathrm{g} / \mathrm{ml}\right)$. For dimethomorph, Chabane et al (5) calculated an $\mathrm{EC}_{50}$ of $0.7 \mu \mathrm{g} / \mathrm{ml}$ for inhibition of mycelial growth of $P$. parasitica. Schwinn and Staub (27) report that dimethomorph is more inhibitory to mycelial growth and sporulation than to spore germination in vitro. Our results for $P$. capsici, $P$. citrophthora, and $P$. parasitica are similar, with mycelial growth $\left(\mathrm{EC}_{90}<1.0 \mu \mathrm{g} / \mathrm{ml}\right)$ and sporulation $\left(\mathrm{EC}_{90}\right.$ ranging from 0.32 to $1.6 \mu \mathrm{g} / \mathrm{ml}$ ) appearing to be more sensitive to dimethomorph than germination of zoospore cysts $\left(\mathrm{EC}_{90}\right.$ ranging from 5.6 to 21 $\mu \mathrm{g} / \mathrm{ml}$ ). On the other hand, Cohen et al. (7) found that, for $P$. infestens, dimethomorph was more inhibitory to zoospore cyst germination $(97 \%$ reduction at a concentration of $0.015 \mu \mathrm{g} / \mathrm{ml}$ ) than to mycelial growth (90\% reduction at $0.3 \mu \mathrm{g} / \mathrm{ml}$ ) and sporulation $(52 \%$ reduction at $500 \mu \mathrm{g} / \mathrm{ml})$. Fluazinam has been reported to strongly inhibit germination of zoospores of $P$. infestans (1). Our data suggest that zoospore motility and sporangium formation by $P$. capsici, $P$. citrophthora, and $P$. parasitica are more sensitive than zoospore cyst germination to this compound.

Table 1. Range of $\mathrm{EC}_{50}$ and $\mathrm{EC}_{90}$ values of five different fungicides for mycelial growth, sporangium formation, zoospore motility, and encysted zoospore germination of Phytophthora capsici, $P$. citrophthora, and $P$. parasitica ${ }^{\mathrm{a}}$

\begin{tabular}{|c|c|c|c|c|c|c|}
\hline \multirow[b]{2}{*}{ Fungicide } & \multicolumn{3}{|c|}{$\mathrm{EC}_{50}(\mu \mathrm{g} / \mathrm{ml})$} & \multicolumn{3}{|c|}{$\mathrm{EC}_{90}(\mu \mathrm{g} / \mathrm{ml})$} \\
\hline & P. capsici & P. citrophthora & $P$. parasitica & P. capsici & P. citrophthora & P. parasitica \\
\hline \multicolumn{7}{|l|}{ Mycelial growth } \\
\hline Azoxystrobin & $>3,000$ & 138 & $>3,000$ & $>3,000$ & $>3,000$ & $>3,000$ \\
\hline Dimethomorph & $<0.1$ & 0.14 & 0.38 & 0.64 & 0.32 & 1.6 \\
\hline Fluazinam & 80.5 & 2.9 & $<0.1$ & $>3,000$ & $>3,000$ & $>3,000$ \\
\hline Fosetyl-Al & 103 & 23.6 & 30.8 & 402 & 404 & 381 \\
\hline Metalaxyl & 0.16 & $<0.1$ & 0.38 & 10.0 & 725 & 40.2 \\
\hline \multicolumn{7}{|c|}{ Sporangium formation } \\
\hline Azoxystrobin & 3.3 & $<1.0$ & 5.0 & 57.8 & 1.9 & 27.8 \\
\hline Dimethomorph & $<1.0$ & $<1.0$ & $<1.0$ & $<1.0$ & $<1.0$ & $<1.0$ \\
\hline Fluazinam & $<1.0$ & $<1.0$ & $<1.0$ & $<1.0$ & 2.2 & 6.0 \\
\hline Fosetyl-Al & 6.0 & 3.1 & 12.0 & 33.4 & 20.0 & 208 \\
\hline Metalaxyl & $<1.0$ & 1.1 & $<1.0$ & 3.0 & 10.0 & $<1.0$ \\
\hline \multicolumn{7}{|c|}{ Duration of zoospore motility } \\
\hline Azoxystrobin & 0.10 & 1.7 & 0.002 & 26.8 & 16.0 & 0.65 \\
\hline Dimethomorph & 24.0 & 12.0 & 6.8 & 139 & 105 & 72 \\
\hline Fluazinam & $<0.001$ & $<0.001$ & $<0.001$ & $<0.001$ & $<0.001$ & $<0.001$ \\
\hline Fosetyl-Al & 334 & 299 & 317 & 680 & 518 & 519 \\
\hline Metalaxyl & 12.5 & 12.0 & 13.0 & 24.0 & 38.2 & 37.0 \\
\hline \multicolumn{7}{|c|}{ Zoospore cyst germination } \\
\hline Azoxystrobin & 700 & 530 & 256 & $>1,000$ & $>1,000$ & $>1,000$ \\
\hline Dimethomorph & 3.9 & 3.3 & 7.2 & 21.0 & 5.6 & 21.0 \\
\hline Fluazinam & 108 & 18 & 100 & 820 & 67 & $>1,000$ \\
\hline Fosetyl-Al & 317 & 326 & $>1,000$ & 510 & 545 & $>1,000$ \\
\hline Metalaxyl & 32 & 34 & 280 & 49 & 56 & 529 \\
\hline
\end{tabular}

${ }^{\mathrm{a}} \mathrm{EC}_{50}$ and $\mathrm{EC}_{90}$ values are the concentrations of each fungicide causing 50 and $90 \%$ reduction, respectively, in mycelial growth, sporangium formation, zoospore motility, and germination of encysted zoospores compared to the absence of a fungicide. These values were estimated from the fitted regression line of the logit-transformed percent inhibition plotted against the log-transformed fungicide concentration. 
There is considerable diversity in the published data concerning the relative activity of each chemistry on mycelial growth, sporulation, and zoospore cyst germination. Possible reasons for these discrepancies could include variability due to the different Phytophthora spp. tested, variability among different isolates of the same species, and differences due to the techniques employed to assess fungicide activity.

Each of the chemistries tested in this study has a unique mode of action at the biochemical level. Strobilurin analogues, such as azoxystrobin, inhibit mitochondrial respiration by blocking electron transfer at the cytochrome $b_{1}$ complex (3). Circumvention of this cytochrome $b_{1}$ target site by induction of the alternative oxidase respiratory pathway has been proposed as the likely reason for low mycelial sensitivity to strobilurins displayed by several pathogens (26). This alternative oxidase respiratory pathway is utilized by fungi growing on agar, especially nutrient-rich agar, and could account for the low sensitivity to azoxystrobin that we observed for $P$. capsici, $P$. citrophthora, and P. parasitica grown on CMA containing this compound. Kune et al. (20) suggests that dimethomorph acts on the biochemical processes associated with cell wall biogenesis. Fluazinam has been shown to actively uncouple oxidative phosphorylation (19). The biochemical target area for fosetyl-Al is amino acid metabolism (27), whereas phenylamides, including metalaxyl, interfere with RNA synthesis of target fungi (8). Each compound has a different mode of action; therefore, these chemistries could be incorporated into a disease management program that could minimize the risk of development of resistance by Phytophthora spp. and, at the same time, maximize disease control.

In our investigations, the relationship between $\mathrm{EC}_{50}$ and $\mathrm{EC}_{90}$ values was highly dependent upon the chemical under evaluation as well as the species and biological function of Phytophthora that was being measured. These investigations revealed a difference between $\mathrm{EC}_{50}$ and $\mathrm{EC}_{90}$ values ranging from 0 to $>1,000$-fold. $\mathrm{EC}_{50}$ values often are calculated in studies assessing the potential value of a molecule to control growth or sporulation of a pathogen. As a practical matter, reducing growth and especially sporulation or spore survival of Phytophthora spp. by $50 \%$ will not usually provide an acceptable level of disease control. For evaluation and comparison of molecules as potential chemical disease management tools, $\mathrm{EC}_{90}$ rather than $\mathrm{EC}_{50}$ values for growth and inoculum reduction would seem to be more beneficial.

The activity of azoxystrobin, dimethomorph, and fluazinam on one or more stages of the life cycle of $P$. capsici, $P$. citrophthora, and $P$. parasitica suggests that these compounds could provide Phy- tophthora spp. disease control comparable to that of the established fungicides fosetyl-Al and metalaxyl. Evaluation of these compounds for control of some diseases caused by $P$. capsici, $P$. citrophthora, and $P$. parasitica are in progress.

\section{LITERATURE CITED}

1. Anema, B. P., Bouwmann, J. J., Komyoji, T., and Suzuki, K. 1992. Fluazinam: a novel fungicide for use against Phytophthora infestans in potatoes. Proc. Br. Crop Prot. Conf.-Pests Dis. 2:663-668.

2. Benson, D. M. 1979. Efficacy and in vitro activity of two systemic acylalanines and ethazole for control of Phytophthora cinamomi root rot of azalea. Phytopathology 69:174-178

3. Brandt, U., Schägger, H., and von Jagow, G. 1988. Characterization of binding of the methoxyacrylate inhibitors mitochondrial cytochrome $\mathrm{c}$ reductase. Eur. J. Biochem. 173:499-506

4. Brantner, J. R., and Windels, C. E. 1998. Variability in sensitivity to metalaxyl in vitro, pathogenicity, and control of Pythium spp. on sugar beet. Plant Dis. 82:896-899.

5. Chabane, K., Leroux, P., and Bompeix, G. 1993. Selection and characterization of Phytophthora parasitica mutants with ultravioletinduced resistance to dimethomorph or metalaxyl. Pestic. Sci. 39:325-329.

6. Coffey, M. D., and Joseph, M. C. 1985. Effects of phosphorous acid and fosetyl-Al on the life cycle of Phytophthora cinnamomi and P. citricola. Phytopathology. 75:1042-1046.

7. Cohen, Y., Baider, A., and Cohen, B. H. 1995. Dimethomorph activity against oomycete fungal plant pathogens. Phytopathology 85:1500-1506.

8. Davidse, L. C., Hofman, A. E., and Velthius, G. C. M. 1983. Specific interference of metalaxyl with endogenous RNA polymerase activity in isolated nuclei from Phytophthora megasperma f. sp. medicaginis. Exp. Mycol. 7:344-361.

9. Dowley, L. J. 1995. Activity of fluazinam against late blight of potatoes. Ir. J. Agric. Food Res. 34:33-37.

10. Duniway, J. M. 1983. Role of physical factors in the development of Phytophthora diseases. Pages 175-187 in: Phytophthora: Its Biology, Taxonomy, Ecology, and Pathology. D. C. Erwin, S. Bartnicki-Garcia, and P. H. Tsao, eds. APS, St. Paul, MN.

11. Erwin, D. C., and Ribeiro, O. K. 1996. Phytophthora Diseases Worldwide. APS Press, St. Paul, MN.

12. Farih, A., Tsao, P. H., and Menge, J. A. 1981. Fungitoxic activity of efosite aluminum on growth, sporulation and germination of Phytophthora parasitica and $P$. citrophthora. Phytopathology 71:934-936.

13. Farih, A., Tsao, P. H., and Menge, J. A. 1981. In vitro effects of metalaxyl on growth, sporulation, and germination of Phytophthora parasitica and $P$. citrophthora. Plant Dis. 65:651-654.

14. Fenn, M. E., and Coffey, M. D. 1984. Studies on the in vitro and in vivo antifungal activity of fosetyl-Al and phosphorous acid. Phytopathology 74:606-611.

15. Gisi, U., Hermann, D., Ohl, L., and Steden, C. 1997. Sensitivity profiles of Mycosphaerella graminicola and Phytophthora infestans populations to different classes of fungicides. Pestic. Sci. 51:290-298.

16. Glantz, S. A. 1992. Primer of Biostatistics, 3rd ed. McGraw-Hill Book Co., New York.

17. Godwin, J. R., Anthony, V. M., Clough, J. M., and Godrey, C. R. A. 1992. ICIA-5504: A novel, broad spectrum, systemic $\beta$-meth- oxyacrylate fungicide. Proc. Br. Crop Prot. Conf.-Pests Dis. 1:435-442.

18. Gregory, P. H. 1983. Some major epidemics caused by Phytophthora. Pages 271-278 in: Phytophthora: Its Biology, Taxonomy, Ecology, and Pathology. D. C. Erwin, S. BartnickiGarcia, and P. H. Tsao, eds. APS, St. Paul, MN.

19. Guo, Z., Miyoshi, H., Komyoji, T., Taga, T., and Fugita, T. 1991. Uncoupling activity of a newly developed fungicide, fluazinam [3chloro-N-(3-chloro-2, 6-dinitro-4-trifluoro methylphenyl)-5-trifluromethyl-2-pyridinamine]. Biochem. Biophys. Acta 1056:8992.

20. Kuhn, P. J., Pitt, D., Lee, S. A., Wakley, G., and Sheppard, A. N. 1991. Effects of dimethomorph on the morphology and ultrastructure of Phytophthora. Mycol. Res. 95:333-340.

21. Marks, G. C., and Smith, I. W. 1990. Control of experimental Phytophthora cinnamomi stem infections of Rhododendron, Leucadendron, and Eucalyptus by dimethomorph, fosetyl-Al and metalaxyl. Aust. J. Exp. Agric. 30:139-143.

22. Matheron, M. E., and Matejka, J. C. 1995. Comparative activities of sodium tetrathiocarbonate and metalaxyl on Phytophthora capsici and root and crown rot on chili pepper. Plant Dis. 79:56-59.

23. Matheron, M. E., and Porchas, M. 1995. Comparison of five fungicides to metalaxyl with respect to sporulation of Phytophthora capsici and development of stem and root rot on chili pepper. (Abstr.) Phytopathology 85:1126.

24. Matheron, M. E., and Porchas, M. 1996. Activity of six different compounds on sporulation and growth of Phytophthore citrophthora and P. parasitica. (Abstr.) Phytopathology 86:S111.

25. Matheron, M. E., Porchas, M., and Matejka, J. C. 1997. Distribution and seasonal population dynamics of Phytophthora citrophthora and $P$. parasitica in Arizona citrus orchards and effects of fungicides on tree health. Plant Dis 81:1384-1390.

26. Olaya, G., Zheng, D., and Köller, W. 1998. Differential responses of germinating Venturia inequalis conidia to kresoxim-methyl. Pestic. Sci. 54:230-236.

27. Schwinn, F., and Staub, T. 1995. Oomycetes fungicides. Pages 323-346 in: Modern Selective Fungicides: Properties, Applications, Mechanisms of Action. H. Lyr, ed. Gustav Fischer Verlag, New York.

28. Simons, J. N., Simons, J. E., and Winsberg, T. 1991. Control of Phytophthora crown rot in bell pepper with directed sprays of metalaxyl. Proc. Annu. Meet. Fla. State Hortic. Soc. 103:120-121

29. Steinhausen, W. R. 1979. On the importance of plant pathogenic organisms assessed by literature studies. Z. Pflanzenkrankh. Pflanzenschutz 86:86-92.

30. Sung, N. K., and Hwang, B. K. 1988. Comparative efficacy and in vitro activity of metalaxyl and metalaxyl-copper oxychloride mixture for control of Phytophthora blight of pepper plants. Kor. J. Pathol. 4:185-196.

31. Timmer, L. W., and Castle, W. S. 1985. Effectiveness of metalaxyl and fosetyl $\mathrm{Al}$ against Phytophthora parasitica on sweet orange. Plant Dis. 69:741-743.

32. van der Plank, J. E. 1963. Plant Diseases: Epidemics and Control. Academic Press, New York.

33. Washington, W. S., Shanmuganathan, N., and Forbes, C. 1992. Fungicide control of strawberry fruit rots, and the field occurrence of resistance of Botrytis cinerea to iprodione, benomyl and dichlofluanid. Crop Prot. 11:355-360. 